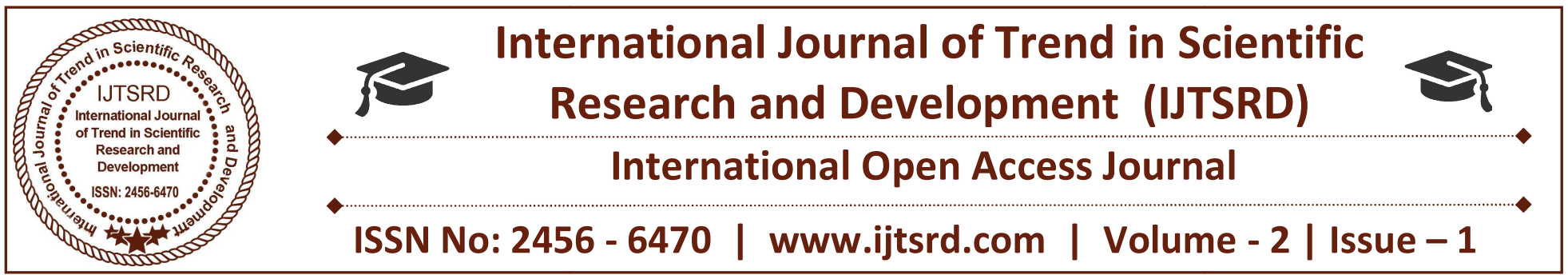

\title{
Essays of Francis Bacon A Moral Perspective
}

\author{
Ishfaq Hussain Bhat \\ Ex Student \\ Department of English University of Kashmir
}

\begin{abstract}
"It is a strange desire, to seek power, and to lose liberty; or to seek power over others, and to lose power over man's self." -- Bacon

Francis Bacon (1561-1626), the father of English essay, is a central figure in the entire history of English literature in general and in prose of the Jacobean period in particular. Bacon's essays are the expression of a life-time of experience in the world of men and affairs and as such present valuable advice to the readers characterized by terseness and brevity. His pithy statements in the essays are not confined to the people of the period that he lived in but are still valid and, therefore, have a universal application. The aim of this paper is to explore Bacon's essays from moral perspective in order to highlight the valuable advice that Bacon gives to mankind in general and to his readers in particular for the purpose of cultivating moral or virtuous character.
\end{abstract}

Keywords: Ethics, morals, vice, repugnance, virtue, reverence, counsel, worldly wisdom, successful life.

"The great end of life is not knowledge but action."

--Bacon

Francis Bacon's essays replete with worldly wisdom were first published in 1597.The first edition Essayes: Religious Meditations. Places of Perswasion and Disswasion. Seene and Allowed contained 10 essays. The enlarged second edition published in 1612 contained 38 essays and the third edition Essayes or Counsels, Civil and Morall (1625) contained 58 essays.
There is no doubt that Bacon's essays are treasure house of worldly wisdom. The essays are replete with the art which one should employ for achieving success in his life.

\section{OF RICHES}

"Of great riches there is no real use, except it be in the distribution; the rest is but conceit."

The essay OF RICHES presents a lot of valuable advice which everyone should employ to make his life a successful one. Here Bacon emphasizes the importance of distributing wealth among others. A man needs only a certain amount of riches for the satisfaction of his desires and beyond that it gives him an imaginary pleasure. He further moves on to say that great riches have more often landed their owners in difficulty rather than taking them out of it:

"And the care of it (riches) sometimes loseth or disturbeths the victory."

This reminds the reader about Shakespear's remarkable observation about wealth, power:

"Uneasy lies the head that wears a crown."

Bacon goes on to advice his reader by saying that one should not seek riches just for the sake of ostentation and one should seek riches only through fair means. Bacon emphasizes that one should not renounce riches altogether:

"Seek not proud riches, such as thou mayest get justly...yet have no abstract or frairly contempt of them.'” 
Bacon tries to instill into the minds of his readers a deep repugnancy towards parsimony which becomes a hurdle in the way of charity. Bacon encourages his readers to improve the soil and to cultivate it. He considers this method sufficient enough to make a lot of wealth through honest ways. Moreover, he also encourages the trade of timber merchants, owners of coal mines, sheep owners, etc. which is a source of honest money:

"The ways to enrich are many and most of them foul. Parsimony is one of the best, and yet is not innocent; for it withholdeth men from works of liberality and charity. The improvement of the ground is the most natural way of obtaining the riches... It multiplieth riches exceedingly."

Bacon goes on to say that usury is one of the worst ways of making money because the money-lender exploits the people who are in need of money. Moreover, Bacon also calls riches acquired through flattery as money acquired in the worst way:

"When they (riches) are gotten by flattery, feeding humors, and other servile conditions, they may be placed amongst the worst."

Bacon concludes his essay with a remarkable observation:

"Measure not thine advancements by quantity, but frame them by measure. And defer not charities till death."

\section{OF EXPENSE}

The essay OF EXPENSE throws a considerable light on spending riches: The expenditure should be determined by the importance of the occasion:

"Therefore, extraordinary expense must be limited by the worth of the occasion."

Moreover, one should not be too sudden in selling his estate in case of debt nor delay the sale for too long. This again is a valuable advice from treasure house of worldly wisdom of one of the greatest essayists in English:

"In clearing of man's estate, he may as well hurt himself in being too sudden, as in letting it run on too long."

\section{OF TRUTH}

OF TRUTH is a essay written in didactic tone. Bacon in this essay tries to instill into the mind of his readers reverence for truth and, likewise, a deep repugnance for falsehood. Bacon's advice to his readers is that the inquiry of truth, the knowledge of truth, and the belief of truth are the highest good for human beings. He calls the love for lies "corrupt love of the lie itself".

His comparison of falsehood to an alloy in a coin of gold or silver is remarkable. The alloy makes the metal work better, but it lowers its value. The dishonest ways may be useful at times but they lower the dignity of the individual (the liar):

"And that mixture of falsehood is like alloy in coin of gold or silver, which may make the metal work the better, but it embaseth it."

He further advises his readers that there is no vice more grave and shameful than a lie. The detection of a lie results in the embarrassment of the liar:

"There is no vice that doth so cover a man with shame as to be found false and perfidious."

Bacon in order to instill virtuous character in his readers compares dishonest and crooked ways of life to the movements of the serpent:

"For these winding and crooked courses are the goings of the serpent, which goes basely upon the belly, and not upon the fret."

\section{OF FRIENDSHIP}

"Whosoever is delighted in solitude, is either a wild beast or a god."

In this essay Bacon highlights the importance of social life of an individual. Bacon thus underscores the dependence of an individual on others in a society. A man as a social animal cannot live in isolation for only a wild beast or a god can live in isolation. This statement, in a way, is in line with Aristotle's observation " Man, by nature, is a social animal'.

"A principal fruit of friendship is the ease and discharge of the fullness and swellings of the heart, which passions of all kinds do cause and induce."

Bacon tries to illustrate various benefits and uses of friendship. The main benefit of friendship is that it enables a man to give an outlet to his emotions and 
feelings. One can share one's misery, joy, fears and other feelings with a friend. And this, in turn, eases the mental strain of the person:

"But to a true friend; to whom you may impart griefs, joys, fears, hopes, suspicions, counsels, and whatsoever lieth upon the heart...moreover, a man's joy will greatly increase when he speaks about it to his friend and his grief will decrease by imparting it to a friend."

Bacon draws the attention of his readers to the fact that being surrounded by a lot of people does not mean that they are your friends. The people around a person may not be his well-wishers, therefore, one should only confide in one's true friends:

"For crowd is not company; and faces are but a gallery of pictures; and talk about a tinkling cymbal, where there is no love."

\section{OF AMBITION}

In this essay Bacon shows his great knowledge of human nature. The idea presented in the essay is that ambition within limits makes man active and energetic but, if it is allowed to grow unchecked, it makes a man malicious and dangerous. The essay can be of great use to Kings, Presidents, Prime Ministers, Chief Ministers and other high dignitaries for the essay contains some valuable advice for them. It provides a roadmap whereby they can run their government smoothly with little chances of dissatisfaction on the part of the people:

"Ambition is like a Choler; which is a humor that maketh men active, earnest, full of alacrity, and stirring, if it be not stopped; it becometh adust, and thereby malign and venomous."

\section{OF SUSPICION}

This essay deals with another aspect of human life. Suspicion, according to Bacon, should be suppressed or controlled because they darken one's mind. Suspicions darken the mind so much that even wise men fall prey to it and, therefore, fail to make judicious decisions. Suspicion makes a king tyrant and who in turn makes the life of the people miserable. Suspicions, at times if not controlled, makes the husbands jealous and thus ruin the lives of the married people :

"Certainly they (suspicions) are to be repressed, or at least well guarded: for they cloud the mind; they leese friends; and they check with business... they dispose Kings to tyranny, husbands to jealousy, wise men to irresolution and melancholy."

\section{OF PARENTS AND CHILDREN}

The essay contains some valuable advice about the relationship of parents with their children. It calls the difference in affection of parents towards their several children 'unworthy'.

It throws a considerable light on the upbringing of the children, the behavior parents towards their children, and it even talks about the fixation of pocket allowances of the children:

"The illiberality of parents, in allowance towards their children, is a harmful error, makes them base... and makes them surfeit when they come to plenty."

\section{OF REVENGE}

"This is certain, that a man that studieth revenge keeps his own wounds green, which otherwise would heal and do well...Certainly, in taking revenge, a man is but even with his enemy, but in passing it over, he is superior; for it is a prince's part to pardon."

OF REVENGE is one of the best essays written by Bacon. Bacon in this essay enlightens the readers about another darker aspect of life. OF REVENGE is a representative essay of Bacon in which he gives sagacious and judicious advice to his readers. Bacon aims at inculcating a sense of forgiveness in his readers. One who constantly thinks about getting revenge on someone who has hurt him, never allows one's wounds heal and thus keeps the wounds green. Forgiving someone not only helps us heal the wounds but also shows our superior temperament. Moreover, if we think constantly about our past it affects our present and which, in turn, ruins our future. Therefore, this essay imparts a remarkable outlook that we should inculcate in ourselves.

"That which is past is gone and irrevocable, and wise men have enough to do with things present and to come."

Bacon's essays cover both private and public life of the people. He criticizes the materialist outlook of people in the following statement:

"Money is a great servant but a bad master." 
Everyone should keep this proverb in mind for it emphasizes the fact that it is good to have money but it should not be given so much importance that it starts ruling one's life. It should never diminish the importance of other things like parents, children, society. Therefore, one should be wise enough not to run after it at the cost of other valuable things.

Hudson while acknowledging the merit and moral appeal of Bacon's essays says :

"His essays are loaded with ripest wisdom of experience."

Bacon rightly called his essays "Counsels, Civil and Moral". Bacon's essays are replete with worldly wisdom. He counsels his readers in every aspect of life; be it the upbringing of the children, earning and spending money, business dealings, etc. or virtues like truthfulness, honesty, righteousness, tolerance. His essays are loaded with moral appeal. He presents his argument so artistically that one feels a deep repugnance for vice and a great reverence for virtue. His essays thus not only help in promoting individual greatness but also help in the promotion of collective good and greatness.

\section{Works Cited:}

Walker, Hugh. The English Essay and Essayists. 1915

Abbott, Edwin A. Bacon, An Account of His Life and Works 1885

----Bacon's Essays Edited by F.G. Selby. 1889

----Bacon's Essays. RAMA BROTHERS INDIA PVT. LTD. 